\title{
Pathogen control using a natural Chilean bee pollen extract of known botanical origin
}

\author{
Carol Cabrera, and Gloria Montenegro \\ Facultad de Agronomía e Ingeniería Forestal, Pontificia Universidad Católica de Chile. Casilla 306-22, \\ Santiago, Chile.
}

\begin{abstract}
C. Cabrera, and G. Montenegro. 2013. Pathogen control using a natural Chilean bee pollen extract of known botanical origin. Cien. Inv. Agr. 40(1):223-230. Bee pollen is a product from beehives that is contained in corbiculae, generally monospecific and is currently considered as a functional food due to its nutritional and medicinal properties. This study investigates the antimicrobial activity of a Chilean bee pollen extract of known botanical origin. The botanical origin of the pollen was determined by palynological analysis, and then an aqueous extract was prepared. The antibacterial properties of the extract were evaluated on human infectious agents (Escherichia coli, Pseudomonas aeruginosa, Staphylococcus aureus and Streptococcus pyogenes) using a qualitative method (agar diffusion) and a quantitative method (minimum inhibitory and bactericide concentration) and on agricultural pathogens (Alternaria alternata, Botrytis cinerea and Fusarium oxysporum) using the poisoned food technique. The bee pollen ( $60 \%$ of Azara petiolaris) is considered native, endemic and monofloral. The E. coli and P. aeruginosa became resistant to the extract, while $S$. aureus and $S$. pyogenes were sensitive. Additionally, the minimum inhibitory concentrations (MICs) of these bacteria were $82.4 \mathrm{mg} \mathrm{mL}^{-1}$ for $E$. coli, $41.2 \mathrm{mg} \mathrm{mL}^{-1}$ for $P$. aeruginosa, and 20.6 $\mathrm{mg} \mathrm{mL}^{-1}$ for $S$. aureus and $S$. pyogenes. Additionally, the extract did not have a complete inhibitory effect on the fungi, but it caused delayed growth in comparison to the control. The development of an aqueous extract from native and endemic bee pollen with antimicrobial properties creates the potential for future research and development of new Chilean natural products, favoring the development of national apiculture.
\end{abstract}

Key words: Antimicrobial activity, bee pollen, aqueous extract.

\section{Introduction}

Floral pollen is one of the main sources of protein for bees (Almeida-Muradian et al., 2005) and is used as food for their offspring. However, before

Received June 6, 2012. Accepted December 6, 2012. Corresponding author: ctcabrer@uc.cl transporting it to the beehive, bees mix pollen with nectar and digestive enzymes and store it within a structure on the hind legs, the corbicula, thus forming bee pollen (Nagai et al., 2004). The pollen contained in corbiculae is generally monospecific (Montenegro et al., 1992) because while travelling from the beehive, bees forage many flowers of the same species to fill their corbiculae (Montenegro et al., 1992; Sá-Otero et al., 2002). 
Generally, bee pollen is a directly consumed product due to its nutritional value in the human diet, and it is currently regarded as a functional food because vegetal proteins are important due to their scarcity in nature (Carpes et al., 2007). Pollen is primarily composed of polysaccharides, simple sugars, lipids, amino acids, proteins and other secondary compounds, such as flavonoids, vitamins, minerals and pigments such as carotenoids (Montenegro et al., 1997; Vit et al., 2008). The use of pollen in traditional medicine is strongly linked to its chemical composition, which depends on the floral origin of bee pollen (Sá-Otero et al., 2002). Additionally, phenolic compounds (principally flavonoids) present in pollen have recently aroused interest due to their antioxidant and antimicrobial activity (Leja et al., 2007; Vit et al., 2008) and positive effects on several pathologies such as diabetes, hypertension and cardiovascular disease (Nagai et al., 2004; Abouda et al., 2011).

Although there are few studies on the antimicrobial activity of bee pollen, some authors show that its antimicrobial activity depends on the botanical origin of the pollen, unlike propolis. Özcan et al. (2004) evaluated the antifungal activity of bee pollen methanolic extracts from different regions in Turkey and showed that they have an inhibitory effect on the growth of some phytopathogens. Additionally, Basim et al. (2006) evaluated the antibacterial activity of methanolic extracts against agricultural bacteria, which were also inhibited by pollen extracts from Turkey. Carpes et al. (2007) studied the effect of methanolic extracts from Brazilian pollen on the growth of pathogenic bacteria and also obtained significant results. However, Carpes et al. (2009) did not obtain positive results using ethanolic extracts from bee pollen from Southern Brazil on human and agricultural bacteria, demonstrating that the antimicrobial activity of bee pollen is dependent on its botanical origin. Finally, two studies from 2011 on the antimicrobial activity on bee pollen extracts from human pathogens (Abouda et al., 2011; Morais et al., 2011) and yeasts (Morais et $a l ., 2011)$ both showed inhibitory effects.
The objective of this study was to evaluate the in vitro antimicrobial activity of aqueous bee pollen extracts derived solely from native Chilean flora on human and agricultural pathogens in relation to the growing interest in natural products, the importance of functional foods, and the effort to the increase the use of less environmentally harmful agricultural products.

\section{Materials and methods}

\section{Sampling bee pollen}

Bee pollen was collected in the Calera de Tango sector of the Metropolitan Region of Chile (33 $36^{\circ}$ ' $\mathrm{S}$ and $70^{\circ} 47^{\prime} \mathrm{W}$ ) in January of 2011 and stored at $-6^{\circ} \mathrm{C}$ before use. The sample contains 250 grams of bee pollen. The pollen was palynologically analyzed according to the methodology of the Chilean Standard NCh3255-2011 (Montenegro et al., 2011) to determine its botanical and geographical origin.

\section{Pathogen culture}

The pathogenic bacteria used in this study, Escherichia coli, Pseudomonas aeruginosa, Staphylococcus aureus and Streptococcus pyogenes, were acquired from the Instituto de Salud Pública (Santiago, Chile). The phytopathogenic fungi Alternaria alternata, Botrytis cinerea and Fusarium oxysporum were provided by Laboratorio AgroLab. The bacteria were grown overnight on trypticase soy agar at $37^{\circ} \mathrm{C}$ for use the following day. The fungi were grown on potato dextrose agar (PDA) at $25^{\circ} \mathrm{C}$ for seven days before use.

\section{Aqueous extract from bee pollen}

Aliquots containing 100 grams of bee pollen were suspended in $100 \mathrm{~mL}$ of distilled water. The mixture was submerged in a sonicating water bath (Branson 2200 Ultrasonic Cleaner, 
Shelton, CT, USA; working frequency of $47 \mathrm{kHz}$ at $30{ }^{\circ} \mathrm{C}$ ) for $1 \mathrm{~h}$ and then centrifuged at 6,030 $\mathrm{x} g$ for $15 \mathrm{~min}$ to harvest the supernatant. The process was repeated four times with the resulting pellet. The five supernatants were combined and filtered using a vacuum pump and grade 4 filter paper. The filtered solution was desiccated in a rotavapor at $45^{\circ} \mathrm{C}$ (Buchi, Flawil, Switzerland). The residue was brought to a final volume of 100 $\mathrm{mL}$ with distilled water. The solution was filtered again using sterile cellulose filters with $0.45 \mu \mathrm{m}$ pores and $0.45 \mu \mathrm{m}$-syringe filters to remove the typical microbiological load from the bee pollen. Additionally, $1 \mathrm{~mL}$ of distilled water and $1 \mathrm{~mL}$ of the extract were weighed, and the extract concentration was calculated to be $82.4 \mathrm{mg}$ of bee pollen $\mathrm{mL}^{-1}$ of extract by the difference in weight.

\section{Determining the bacterial sensitivity}

The bacteria were cultured on $90 \times 15 \mathrm{~mm}$-Petri plates containing $25 \mathrm{~mL}$ of soy agar. Three agar plugs were removed from each plate using a sterile $6 \mathrm{~mm}$-diameter-punch, and $100 \mu \mathrm{L}$ of the extract was placed inside each hole. Four concentrations of the extract were used (25, 50, 75 and $100 \%)$, and distilled water was used as control. This assay was run in triplicate. The plates were incubated at $37^{\circ} \mathrm{C}$ for $24 \mathrm{~h}$. The results were expressed as the diameter of the zone of inhibition (mm).

Determination of the antibacterial activity by the minimum inhibitory concentration (MIC) and minimum bactericidal concentration (MBC) methods

The dilution method was used to determine the minimum inhibitory concentration (MIC) (Hogg, 2005). Ten 12 × $75 \mathrm{~mm}$-assay tubes containing $0.5 \mathrm{~mL}$ of soy broth were prepared for each bacterial species to be tested. Then, $0.5 \mathrm{~mL}$ of extract was added to the first tube and was subsequently diluted $1: 2$ by placing $0.5 \mathrm{~mL}$ from the first tube into the second and so on. Once the dilutions were made, $50 \mu \mathrm{L}$ of bacterial culture was added to each tube $\left(10^{5}-10^{6} \mathrm{CFU} \mathrm{mL}^{-1}, 0.5\right.$ McFarland) and incubated for $24 \mathrm{~h}$ at $37^{\circ} \mathrm{C}$. The tube without bacterial growth was identified to determine the MIC (according to the turbidity compared with the control treatment). This assay was run in triplicate.

The minimum bactericidal concentration (MBC) was determined using the cultures from the MIC test as follows: a $10 \mu \mathrm{L}$ aliquot was taken from each tube and plated within one of 10 pre-marked sections on a Petri dish containing trypticase soy agar. The plate was incubated for $24 \mathrm{~h}$ at $37^{\circ} \mathrm{C}$. The MBC was determined by identifying the section that lacked bacterial growth. This assay was run in triplicate.

\section{Antifungal activity}

The poisoned food technique was used to determine the fungistatic activity as previously described (Grover and Moore, 1962), but with slight modifications: 35 x 15 mm-Petri plates were filled with $3 \mathrm{~mL}$ of PDA and poisoned with three different concentrations of the extract $(25,50$ and $75 \%$ ). Agar plugs were removed from the fungal culture after seven days using a $3 \mathrm{~mm}$-diameter punch and inserted into the center of each plate with poisoned medium. The plates were incubated at $25^{\circ} \mathrm{C}$, and the diameter of growth was measured daily until the fungus occupied the entire plate in the control treatment (PDA with distilled water). This assay was run in triplicate. The fungicidal activity of extract was determined based on the results of the fungistatic activity test. The agar plugs from plates on which no partial inhibition of growth was observed were placed in $35 \times 15$ mm-Petri plates with PDA medium. The plates were incubated at $25^{\circ} \mathrm{C}$, and the diameter was measured daily. 
Experimental design and data analysis

The experiments were conducted under a completely randomized design. To assess the variation of the data obtained in the evaluation of antimicrobial activity, we performed an analysis of variance and means comparison test (LSD Fisher), using InfoStat software, version 2012.

\section{Results and discussion}

\section{Determination of the pollen botanical origin}

The analyzed bee pollen was composed of pollen from seven floral species (Figure 1), of which one was identified only at the genus level (Brassica sp.). Five of the seven species are introduced, and the other two are native and endemic from Chile (Table 1). Azara petiolaris is the predominant species in the sample (60\%) followed by Brassica sp. (30\%), Raphanus sativus and Adesmia confusa (3.33\% each), Datura stramonium, Rubus ulmifolius and Lotus corniculatus (1.67\% each) (Figure 1).

The bee pollen sample is categorized as monofloral, endemic and native according to the Chilean Standard NCh3255.c2011 (Montenegro et al., 2011) due to its $60 \%$ A. petiolaris pollen content, which may indicate that the antimicrobial properties of the bee pollen extract are derived primarily from the $A$. petiolaris pollen.

\section{Antibacterial activity}

The antibacterial activity results obtained by the agar diffusion method indicate that of the four evaluated bacterial species, only $S$. aureus and $S$. pyogenes were inhibited, whereas the extract did not have an effect on E. coli and P. aeruginosa growth. However, the inhibition of the effected bacteria occurred only at the 50, 75 and $100 \%$ concentrations, and the extract did not show activity at lower concentrations ( $25 \%$ ) when compared to the control treatment. Additionally, S. pyogenes was more sensitive to the extract than $S$. aureus, reaching an average inhibition halo of 14.78 and $17.15 \mathrm{~mm}$ at 75 and $100 \%$, respectively, whereas the halo formed in $S$. aureus reached an approximate diameter of 12.37 and $14.04 \mathrm{~mm}$ at the same concentrations (Figure 2). It was also observed that in S. aureus, the results obtained at the $50 \%$ concentration are statistically equivalent to those obtained with the $75 \%$ concentration, while the latter are comparable to those obtained with the

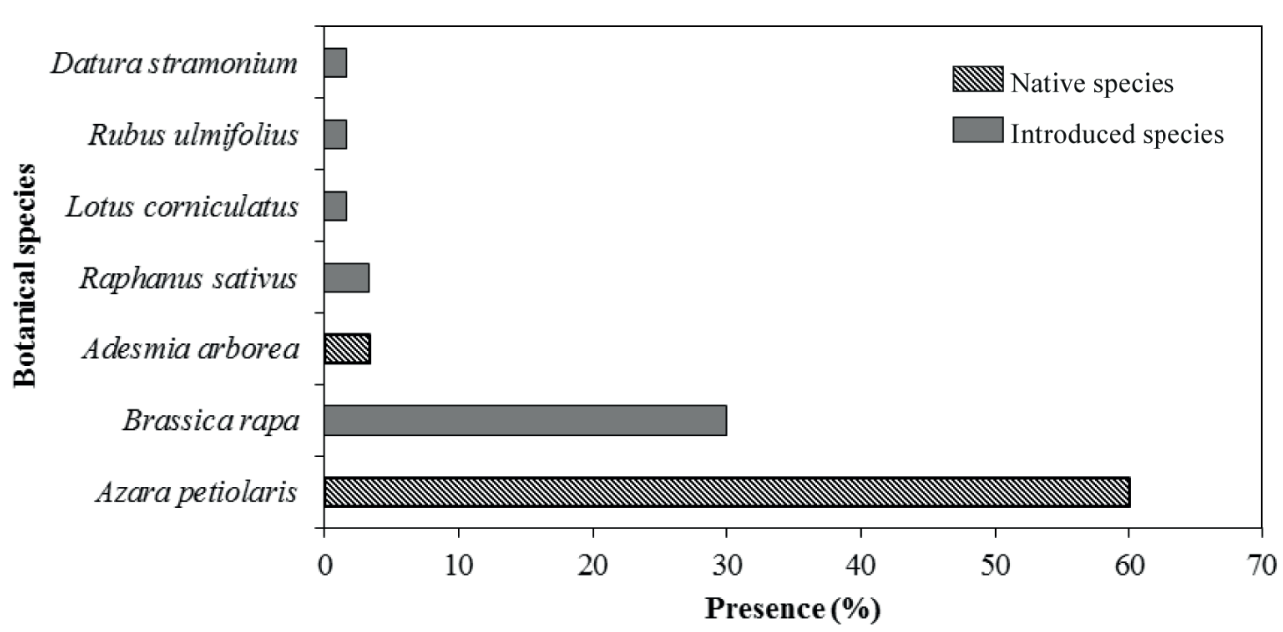

Figure 1. Botanical species, their respective presence (\%), and typology (native or introduced) according to the botanical origin results for the bee pollen sample. 


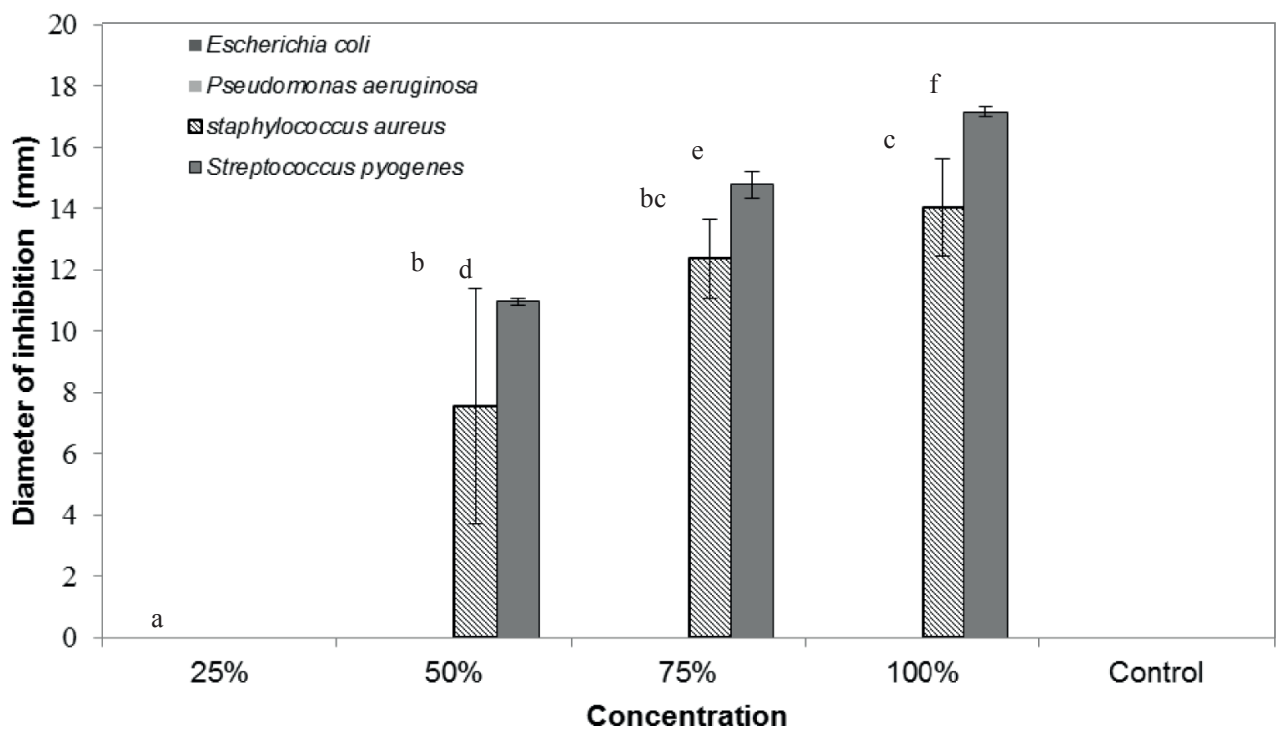

Figure 2. Determination of the bacterial sensitivity by the agar diffusion method. The diameters of the zones of inhibition are shown in $\mathrm{mm}$ at different concentrations of bee pollen extract for each bacterium, \pm the standard deviation. Means with a common letter are not significantly different $(\mathrm{P} \leq 0.05)$.

$100 \%$ concentration. However, for S. pyogenes, the results obtained for the three concentrations were significantly different.

With regard to the MIC results, the four bacterial species were inhibited by the extract, but at different concentrations. The MIC for $S$. aureus and $S$. pyogenes was $20.6 \mathrm{mg}$ of pollen $\mathrm{mL}^{-1}$ of extract, for $P$. aeruginosa, the MIC was 41.2 $\mathrm{mg}$ of pollen $\mathrm{mL}^{-1}$ of extract and for E. coli, it was $82.4 \mathrm{mg}$ of pollen $\mathrm{mL}^{-1}$ of extract. These results indicate that $E$. coli and $P$. aeruginosa are inhibited at a higher concentration of extract than $S$. aureus and $S$. pyogenes. On the other hand, the results from the MBC showed that the $A$. petiolaris extract only had a bactericidal effect on $S$. pyogenes at a concentration of $82.4 \mathrm{mg}$ of pollen $\mathrm{mL}^{-1}$ of extract. The other three bacteria continued to grow when they were transferred to new culture medium; therefore, the extract only had an inhibitory effect on them.

The fact that Gram-negative bacteria (E. coli and $P$. aeruginosa) were not affected by the extract in the agar diffusion method and were affected at higher extract concentrations (MIC) could be because the outer membrane present in this type of bacteria is absent in the Gram-positive bacteria (S. aureus and $S$. pyogenes). Thus, they are more resistant to hydrolytic enzymes, surfactants, biliary salts and hydrophobic antibiotics than the Gram-positive bacteria (Kim and Gadd, 2008). Additionally, the $\mathrm{MBC}$ results confirm the higher resistance of the Gram-negative bacteria to some types of treatment.

\section{Fungistatic activity}

With regard to the fungistatic activity of the extract, only the $25 \%$ and $50 \%$ concentrations caused a decline in the growth of three fungal pathogens compared to the control treatment, while the $75 \%$ concentration inhibited the growth of $A$. alternate until the fourth day of evaluation and completely inhibited the growth of $B$. cinerea and F. oxysporum. In addition, significant differences were found in mycelial growth when different evaluation days were compared (Table 1).

Moreover, the fungicidal activity results of the extract showed that mycelial growth resumed when the inocula were transferred to a new culture 
medium, comparable to the treatment control; therefore, the extract showed no fungicidal activity on all three pathogens studied (Figure 3).

Although the extract did not show a complete inhibitory effect on the fungi, similar results have been observed for $A$. alternata and $F$. oxysporum (Özcan et al., 2004), where the effect of pollen extracts is thought to occur due to various phenolic compounds, which depend directly on the botanical origin of the bee pollen.

Table 1. Average growth per day ( $\mathrm{mm}$ ) of Alternaria alternata, Botrytis cinerea and Fusarium oxysporum with respect to three concentrations of bee pollen extract of Azara petiolaris and its respective control treatment.

\begin{tabular}{|c|c|c|c|c|c|c|c|c|c|}
\hline \multirow[b]{2}{*}{ Pathogen } & \multirow[b]{2}{*}{ Concentration } & \multicolumn{7}{|c|}{ Average growth per day (mm) } & \multirow[b]{2}{*}{ LSD Concentration } \\
\hline & & 1 & 2 & 3 & 4 & 5 & 6 & 7 & \\
\hline \multirow[t]{4}{*}{ Alternaria alternata } & $25 \%$ & $3.0 \mathrm{a}$ & $7.0 \mathrm{~b}$ & $10.8 \mathrm{c}$ & $14.2 \mathrm{~d}$ & $16.6 \mathrm{e}$ & $21.3 \mathrm{f}$ & $21.8 \mathrm{f}$ & $\mathrm{c}$ \\
\hline & $50 \%$ & $1.8 \mathrm{a}$ & $3.3 \mathrm{~b}$ & $6.3 \mathrm{c}$ & $9.0 \mathrm{~d}$ & $11.0 \mathrm{e}$ & $15.3 \mathrm{f}$ & $15.7 \mathrm{f}$ & $\mathrm{b}$ \\
\hline & $75 \%$ & $0.0 \mathrm{a}$ & $0.0 \mathrm{a}$ & $0.0 \mathrm{a}$ & $0.0 \mathrm{a}$ & $0.3 \mathrm{ab}$ & $0.7 \mathrm{~b}$ & $0.7 \mathrm{~b}$ & a \\
\hline & Control & $6.0 \mathrm{a}$ & $14.3 \mathrm{~b}$ & $22.4 \mathrm{c}$ & $27.0 \mathrm{~d}$ & $28.0 \mathrm{e}$ & $28.0 \mathrm{f}$ & $28.0 \mathrm{~g}$ & $\mathrm{~d}$ \\
\hline \multirow[t]{4}{*}{ Botrytis cinerea } & $25 \%$ & $6.9 \mathrm{a}$ & $17.0 \mathrm{~b}$ & $22.3 \mathrm{c}$ & $23.8 \mathrm{~cd}$ & $25.1 \mathrm{de}$ & $27.0 \mathrm{e}$ & $27.0 \mathrm{e}$ & $\mathrm{c}$ \\
\hline & $50 \%$ & $1.3 \mathrm{a}$ & $4.0 \mathrm{a}$ & $6.8 \mathrm{~b}$ & $8.9 \mathrm{bc}$ & $11.0 \mathrm{~cd}$ & $13.4 \mathrm{de}$ & $12.2 \mathrm{e}$ & $\mathrm{b}$ \\
\hline & $75 \%$ & $0.0 \mathrm{a}$ & $0.0 \mathrm{a}$ & $0.0 \mathrm{a}$ & $0.0 \mathrm{a}$ & $0.0 \mathrm{a}$ & $0.0 \mathrm{a}$ & $0.0 \mathrm{a}$ & a \\
\hline & Control & $6.4 \mathrm{a}$ & $18.3 \mathrm{~b}$ & $28.0 \mathrm{c}$ & $28.0 \mathrm{c}$ & $28.0 \mathrm{c}$ & $28.0 \mathrm{c}$ & $28.0 \mathrm{c}$ & $\mathrm{d}$ \\
\hline \multirow[t]{4}{*}{ Fusarium oxysporum } & $25 \%$ & $3.0 \mathrm{a}$ & $7.8 \mathrm{~b}$ & $14.3 \mathrm{c}$ & $18.0 \mathrm{~d}$ & $22.3 \mathrm{e}$ & $23.3 \mathrm{f}$ & $23.7 \mathrm{f}$ & $\mathrm{c}$ \\
\hline & $50 \%$ & $1.0 \mathrm{a}$ & $5.0 \mathrm{~b}$ & $8.1 \mathrm{c}$ & $11.0 \mathrm{~d}$ & $14.2 \mathrm{e}$ & $16.2 \mathrm{f}$ & $16.2 \mathrm{f}$ & $\mathrm{b}$ \\
\hline & $75 \%$ & $0.0 \mathrm{a}$ & $0.0 \mathrm{a}$ & $0.0 \mathrm{a}$ & $0.0 \mathrm{a}$ & $0.0 \mathrm{a}$ & $0.0 \mathrm{a}$ & $0.0 \mathrm{a}$ & $\mathrm{a}$ \\
\hline & Control & $5.1 \mathrm{a}$ & $6.3 \mathrm{a}$ & $16.1 \mathrm{~b}$ & $22.7 \mathrm{c}$ & $25.0 \mathrm{~d}$ & $26.7 \mathrm{e}$ & $26.7 \mathrm{e}$ & $\mathrm{d}$ \\
\hline
\end{tabular}

Means with a common letter are not significantly different $(\mathrm{P} \leq 0.05)$.

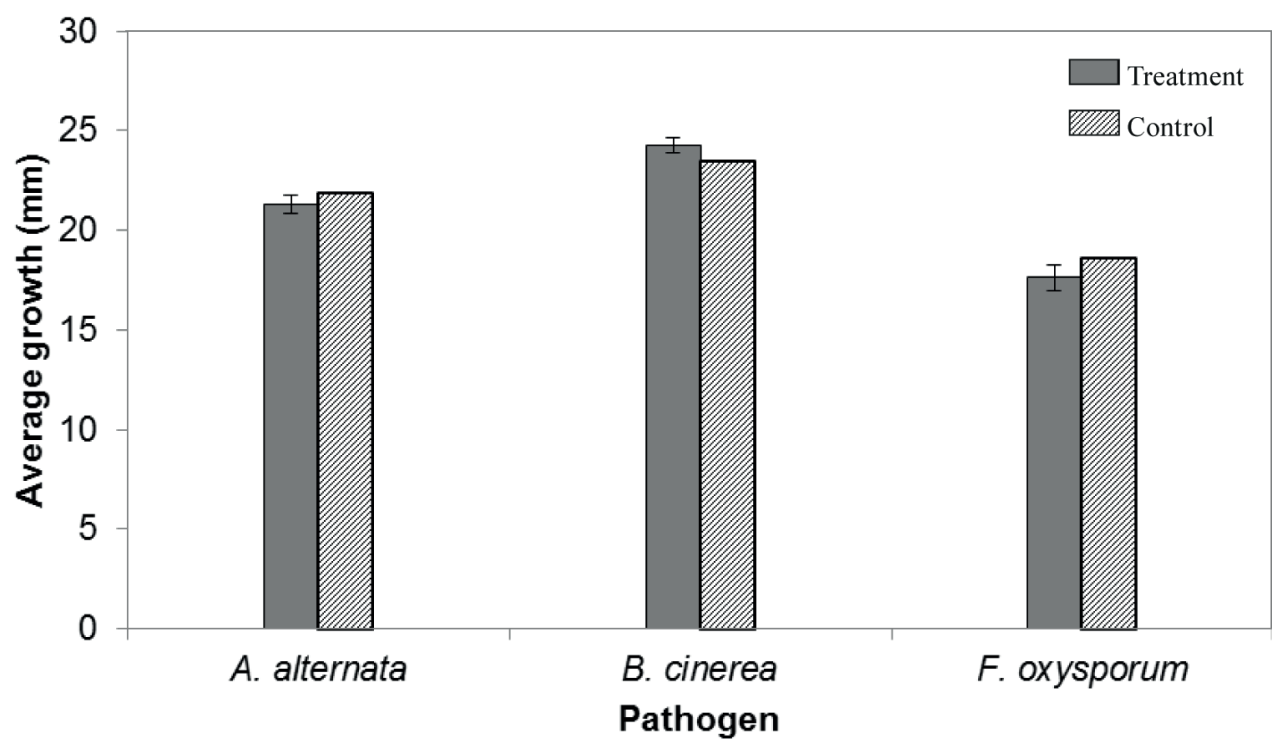

Figure 3. Evaluation of the fungicidal activity of bee pollen extract from Azara petiolaris, measured as average growth (mm) for each pathogen (Alternaria alternata, Botrytis cinerea and Fusarium oxysporum) with respect to their respective control treatment, \pm the standard deviation. Means with a common letter are not significantly different $(\mathrm{P} \leq 0.05)$. 
The main conclusions of the aforementioned research are as follows. The bee pollen extract from the native and endemic Azara petiolaris species showed antibacterial and antifungal activity against the pathogens analyzed. This is crucial, as other authors (Özcan et al., 2004; Basim et al, 2006; Carpes et al., 2007; Carpes et al., 2009; Abouda et al., 2011; Morais et al., 2011) agree that the antimicrobial properties of bee pollen are due mainly to their phenolic components, which are directly related to its botanical origin.

The antimicrobial activity of pollen has become important through the years, mainly due to the development of antibiotic resistant microorganisms; therefore, the development of native bee pollen extracts that are harmless to the environment and human beings is essential as a natural product with specific biological activity. Additionally, the A. petiolaris bee pollen extract is unique in the world due to the endemic nature of the species, giving an added value to the products of the hive.
It is noteworthy that the present research is preliminary with regard to the antimicrobial activity of bee pollen from $A$. petiolaris. Thus, additional experiments must be carried out to determine which factors positively influencing this activity.

\section{Acknowledgements}

This research was carried out under the framework of the FONDEF D08I1080 project awarded to Gloria Montenegro - "Bioprospecting of natural products in bee pollen extracts as functional additives for the Chilean agro-food cluster". We thank the Graduate Program on Thesis in Industry (Conicyt 78111111) for funding "Evaluation of the antimicrobial activity from native Chilean bee pollen" and to the Fellowship granted by the Departamento de Ciencias Vegetales, Facultad de Agronomía e Ingeniería Forestal, Pontificia Universidad Católica de Chile.

\section{Resumen}

C. Cabrera y G. Montenegro. 2013. Control de patógenos mediante el uso de un extracto natural de polen apícola chileno de origen botánico conocido. Cien. Inv. Agr. 40(1):223230. El polen apícola es un producto de la colmena compuesto por corbículas, generalmente monoespecíficas y, debido a sus propiedades nutricionales y medicinales, hoy en día es considerado un alimento funcional. En la presente investigación se estudió la actividad antimicrobiana de un extracto de polen apícola chileno, de origen botánico conocido. Se determinó mediante análisis palinológico el origen botánico del polen y luego se preparó un extracto acuoso. La efectividad del extracto se evaluó en el control de bacterias humanas (Escherichia coli, Pseudomonas aeruginosa, Staphylococcus aureus y Streptococcus pyogenes), mediante un método cualitativo (difusión en agar) y otro cuantitativo (mínima concentración inhibitoria y bactericida) y sobre patógenos del agro (Alternaria alternata, Botrytis cinerea y Fusarium oxysporum), mediante el método del alimento envenenado. El polen apícola resultó ser monofloral (60\% de Azara petiolaris), nativo y endémico. Las bacterias $E$. coli y $P$. aeruginosa resultaron ser resistentes al extracto, mientras que $S$. aureus y $S$. pyogenes fueron sensibles. Además, la concentración mínima inhibitoria (MCI), para E. coli fue de 82,4 $\mathrm{mg} \mathrm{mL} \mathrm{m}^{-1}$, 41,2 $\mathrm{mg} \mathrm{mL}^{-1}$ para $P$. aeruginosa y $20,6 \mathrm{mg} \mathrm{mL}^{-1}$ para $S$. aureus y $S$. pyogenes. Además, se determinó que el extracto no tuvo un efecto inhibitorio completo sobre los hongos, pero sí retardó su crecimiento, con respecto al control. El desarrollo de un extracto acuoso de polen apícola nativo y endémico, con propiedades antimicrobianas, abre una puerta a futuras investigaciones y desarrollo de nuevos productos, favoreciendo así la apicultura nacional.

Palabras clave: Actividad antimicrobiana, extracto acuoso, polen apícola. 


\section{References}

Abouda, Z., I. Zerdani, I. Kalalou, M. Faid, and M.T. Ahami. 2011. The antibacterial activity of Moroccan bee bread and bee-pollen (fresh and dried) against pathogenic bacteria. Research Journal of Microbiology 6:376-384.

Almeida-Muradian, L. B., L. C. Pamplona, S. Coimbra, and O. M Barth. 2005. Chemical composition and botanical evaluation of dried bee pollen pellets. Journal of Food Composition and analysis 18:105-111.

Basim, E., H. Basim, and M. Özcan. 2006. Antibacterial activities of Turkish pollen and propolis extracts against plant bacterial pathogens. Journal of Food Engineering 77:992-996.

Carpes, S. T., R. Begnini, S.M. Alencar, and M.L. Masson. 2007. Study of preparations of bee pollen extracts, antioxidant and antibacterial activity. Ciência y Agrotecnología 31:1818-1825.

Carpes, S. T., I.S.R. Cabral, P.L. Rosalen, S.M. Alencar, and M.L. Masson. 2009. Caracterização do potencial antimicrobiano dos extratos de pólen apícola da região sul do Brasil. Alimentos e Nutrição 20:271-277.

Grover, R. K., and J.D. Moore. 1962. Toximetric studies of fungicides against brown rot organisms, Sclerotia fructicola and S. laxa. Phytophatology 52:876-880.

Hogg, S. 2005. Essential microbiology. John Wiley \& Sons Ltd, The Atrium, Southern Gate, Chichester, England.481 pp.

Kim, B. H., and G.M. Gadd. 2008. Bacterial physiology and metabolism. Cambridge University Press. 529 pp.

Leja, M., A. Mareczek, G. Wyzgolik, J. KlepaczBaniak, and K. Czekonska. 2007. Antioxidative properties of bee pollen in selected plant species. Food Chemistry 100:237-240.
Montenegro, G., M. Gómez, and G. Ávila. 1992. Importancia relativa de especies cuyo polen es utilizado por Apis mellifera en el área de la reserva nacional Los Ruiles, VII Región de Chile. Acta Botánica Malacitana 17:167-174.

Montenegro, G., G. Ávila, D. Rougier, and B. Timmermann. 1997. Pollen loads: Source of carotenoids originating from the mediterranean plant communities of the central zone of Chile. Revista Chilena de Historia Natural 70:91-99.

Montenegro, G., M. Gomez, P. Estay, and X. Ortega. 2011. Polen apícola - Calidad de la colmena para polinización y diferenciación del polen según origen botánico mediante ensayo palinológico. Norma Chilena NCh3255.c2011. Instituto Nacional de Normalización, Santiago, Chile. Versión Final Comité - Septiembre 2011

Morais,M., L. Moreira, X. Feás, and L.M. Estevinho. 2011. Honeybee-collected pollen from five portuguese natural parks: palynological origin, phenolic content, antioxidant properties and antimicrobial activity. Food and Chemical Toxicology 49:1096-1101.

Nagai, T., T. Nagashima, T. Myoda, and R. Inoue. 2004. Preparation and functional properties of extracts from bee bread. Food Nahrung 48:226-229.

Özcan, M., A. Ünver, D.A. Ceylan, and R. Yetişir. 2004. Inhibitory effect of pollen and propolis extracts. Food Nahrung 48:188-194.

Sá-Otero, M. P., S. Marcial-Bugarín, S. ArmestoBaztán, and E. Díaz-Losada. 2002. Método de determinación del origen geográfico del polen apícola comercial. Lazaroa 23:25-34.

Vit, P., P. Herrera, D. Rodríguez, and J. Carmona. 2008. Caracterización de polen apícola fresco recolectado en Cacute, en los Andes venezolanos. Revista del Instituto Nacional de Higiene "Rafael Rangel" 392:7-11. 